\title{
An Exploration of Stree Shakti Programme in Karnataka through Self-Help Groups: With Special Reference to Chitradurga District
}

Kavitha $S^{*}$ and $P$ Laxmana ${ }^{\dagger}$

\begin{abstract}
For the Empowerment of women, government has come up with many schemes. Among those, Self Help Group (SHG) is found to be the strongest route. The purpose of the Programme is to endow women economically and socially by bringing them in self-help groups, and it spent corers of rupees at a time in the project taken up for the development of women and organizing women empowerment in such huge number. The paper articulates the scope and outline of the programme in the SHGs in Chitradurga district and also emphasises on the financial benefits out of it. Through the study, the author tries to bring out the important factors relating to Stree Shakti Programme and SHG model.
\end{abstract}

Keywords: Stree Shakti Programme, Self-help groups, Empowerment of women

\section{Introduction}

Empowerment of women is basically based upon their economic and socio development. Individual or self-development is difficult for poor people, due to lack of socio-financial assistance. It is the responsibility of the government to help them out in this regard, so

* IMA, Bangalore; kavitha.veerendra@gmail.com

† Department of Commerce, Davangere University, Shivagangothri, Davangere 
government has come up with many schemes such as yojana, welfare scheme, and basic minimum services, swarnajayanti gram swarojgaryojana, Stree Shakti, etc. to uplift poor people like indiraaa. Among those, SHG is found to be the strongest route. SHGs are linked to many entities which are monetary institutions like Banks, Non-banking or Financial Institutions, and International Funding Agencies, and Line departments like Health Departments, Agriculture Departments, Animal Husbandry Department, Education, Social Welfare Departments, Community and Rural Development department, NGOs, etc. In Karnataka, Stree Shakti Programme has come into existence under women and child development office which is part of community and Rural Development Department. Streeshakti Programme is launched in Karnataka state on 18 Oct, 2000. The purpose of the programme is to endow women economically and socially by bringing them in self-help groups and it spent 72 crore rupees at a time in the project taken up for the development of the women and organizing women in such huge number. In Karnataka there are 1, 30,000 rural Stree Shakti groups that have been formed in the state and 19.00 lakh women members have been part of these groups. The members have saved Rs 971.84 crores since inception. 1, 21,347 groups have availed bank loans to the extent of Rs 1,195.98 crores and have done internal lending of Rs 2,835.94 crores to take up various income generating activities. During 2011-12 Rs 7.50 lakhs is paid as incentive to Anganawadi workers for monitoring Stree Shakti groups.

\section{Self help groups (SHG)}

SHG is a group of $10-20$ people who are from economically backward and wanting for the financial assistance, pool savings among themselves to create fund. That pooled savings will be lent for interest among the group members, so it helps financially to entire group members. Book keeping and all administration work will be done by the designated members on rotation basis. Steadily loan can be obtained from banks depending upon the sustainability of the SHGs. Even subsidies and incentives are given by government to strengthen SHGs economically and social awareness programmes are conducted to make them socially strong. 


\section{Operational network of Stree Shakti Programme in Karnataka}

Each SHG is connected to Anganwadi centres. Each anganwadi teacher is given some of the SHGs by women and child development office so that she could to monitor the function. Weekly once SHG leaders report to anganwadi teachers about developments in SHGs. Records are maintained by the teachers weekly, and these teachers then report once a month to update the month's information to supervisors; moreover, the supervisors submit updated information to women welfare officers' monthly once.

\section{Brief profile of Chitradurga}

Chitradurga is considered one of the backward districts in Karnataka state and receiving funds from the backward regions grant fund programme (BRGFP). As per 2011 census, it has the population of $16,60,378$. Growth of the population is $9.39 \%$ over the decade 2001-11. Literacy rate is 73.82; Chitradurga has a sex ratio of 969 females for every 1000 males. Chitradurga is one of the hilly areas, rich in mineral deposits and lot of old forts can be seen. The district is divided into 6 taluks. Those are Chitradurga, Hiriyur, Hosadurga, Holalkere, Challakere and Molakalmuru. Though many private and public banks are available in the district, poverty and level of economic growth is not up to the mark. The state government has taken initiatives to develop the district by introducing many programmes, and one among them is SHG model. Therefore, the researcher is trying to evaluate how best Stree Shakti Programme is running successfully by giving socioeconomic support in the district especially for women. For this cause, the researcher collected information from Women and Child development offices of taluks under Chitradurga district.

\section{Objectives of the Stree Shakti Programme}

- To strengthen the process of creating suitable atmosphere which could achieve the financial progress and social status of women

- To form more and more self-help groups throughout the state, to stimulate the confidence and self-reliance in them and to make them have control and hold over the financial resources. 
- To increase the income of poor women by engaging them in earning activities, and to create financial stability among them thereby achieving eradication of poverty.

- To channelize various departments in one direction, to provide opportunities to the members of women groups to get the benefit of the development works of various departments and to take measures for the availability of loans through financing institutions

\section{The results expected from Stree Shakti Programme are}

- One lakh self-help groups have to be united through 15-20 lakhs of women.

- Self-help group's main intention is to make savings. So, it indoctrinates the habit of savings among SHG members and has the plan to make 72 crore rupees of savings through 1520 organized women in one SHG.

- As rural poor women folk become economically selfgoverning, the groups will get conversant with financing institutions, and the members will have credit facility to take up for diverse economic activities which will exterminate poverty.

- The model of self-help groups will blowout to all rural areas and lead to radical changes in women organizations.

- Any productive work can be executed at rural level by the organized women. It helps in improving technical strength and eradication of poverty.

- Organized women get formal platform to solve their socioeconomic problems.

\section{Scope and outline of the Programme}

SHGs have been formed under Anganwadi workers spreading in 175 taluks in the state. The Anganwadi workers will extend cooperation during the first six months to the groups to manage their activities. After six months, the Anganwadi workers will only supervise the work in the next six months. If the groups are not able to manage the work themselves, they can appoint an outsider and give remuneration from the amount of savings the groups 
have in account. After six months the groups have to take measures to initiate internal loans in a small scale and open savings accounts compulsorily in the banks. The supervisors of department have to guide the Anganwadi workers from time to time and at the same time they have to supervise the work. To know the progress of the programme the researcher has collected 3 years of information, that is 2008 to 2011. Though the programme started from 2000, structured data maintained by CDPO offices is from 2008, so information has been gathered since2008.

Table 1: Talukwise SHGs (Rural and urban) in Chitradurga district under Stree Shakti from the year 2008-11

\begin{tabular}{|l|r|r|r|r|r|r|}
\hline District/Taluk & \multicolumn{4}{|c|}{ No. of self help groups (Rural) } & \multicolumn{3}{c|}{$\begin{array}{c}\text { No. of self help groups } \\
\text { (Urban) }\end{array}$} \\
\hline & $2008-9$ & $2009-10$ & $2010-11$ & $2008-9$ & $2009-10$ & $2010-11$ \\
\hline Chitradurga & 1100 & 1100 & 1100 & 85 & 85 & 85 \\
\hline Challakere & 680 & 680 & 680 & 30 & 30 & 30 \\
\hline Hiriyur & 850 & 850 & 850 & 40 & 40 & 40 \\
\hline Holalkere & 650 & 650 & 650 & 20 & 20 & 20 \\
\hline Hosadurga & 990 & 990 & 990 & 30 & 30 & 30 \\
\hline Molakalmuru & 463 & 463 & 463 & 10 & 10 & 10 \\
\hline Total & 4733 & 4733 & 4733 & 215 & 215 & 215 \\
\hline
\end{tabular}

Source: survey data

Chitradurga District holds 4,948 SHGs including rural and urban SHGs till 2010-11. In that, Rural Chitradurga has 4,733 SHGs and urban Chitradurga with 215 SHGs. Above table indicates that urban Chitradurga has got less number of SHGs as compared to Rural Chitradurga. In all the year, the same number of SHGs has been continued because the government has not assigned any projects to form further more SHGs. Therefore, through the years, the same SHG numbers are followed and it has been observed that the rural counterpart has taken convention of this programme than the urban. And below chart and table explains about total number of SHGs and its composition in Chitradurga district. 
Table 2: Talukwise total number of SHGs in Chitradurga district under Stree Shakti from the year 2008-11

\begin{tabular}{|l|r|}
\hline Dist/aluk & Number of SHGs \\
\hline Chitradurga & 1185 \\
\hline Challakere & 710 \\
\hline Hiriyur & 890 \\
\hline Holalkere & 670 \\
\hline Hosadurga & 1020 \\
\hline Molakalmuru & 473 \\
\hline Total & 7948 \\
\hline
\end{tabular}

Source: survey data

Above picture explains about composition of SHGs in Chitradurga District. Chitradurga has got maximum opus by having $24 \%$ of the chunk, Hosadurga has $21 \%$ of the chunk and Hiriyur, Challakere and Holalkere are in next line followed by Hosadurga. Molkalmuru has got least number of SHGs in the district.

Table 3: Talukwise member of SHGs (Rural and urban) in Chitradurga district under Stree Shakti from the year 2008-11

\begin{tabular}{|l|r|r|r|r|r|r|}
\hline District/Taluk & \multicolumn{3}{|l|}{ No. of self help groups (Rural) } & \multicolumn{3}{c|}{$\begin{array}{c}\text { No. of self help groups } \\
\text { (Urban) }\end{array}$} \\
\hline & $2008-9$ & $2009-10$ & $2010-11$ & $2008-9$ & $2009-10$ & $2010-11$ \\
\hline Chitradurga & 16808 & 15621 & 15272 & 1415 & 1493 & 1506 \\
\hline Challakere & 11010 & 11284 & 11284 & 422 & 503 & 533 \\
\hline Hiriyur & 13105 & 12860 & 12860 & 890 & 890 & 890 \\
\hline Holalkere & 11700 & 11700 & 11700 & 363 & 363 & 363 \\
\hline Hosadurga & 17117 & 17102 & 17102 & 540 & 540 & 540 \\
\hline Molakalmuru & 7140 & 7320 & 7320 & 175 & 175 & 175 \\
\hline Total & 76880 & 75887 & 75538 & 3805 & 3964 & 4007 \\
\hline
\end{tabular}

Suurce: survey uald

Table 4: Talukwise total number of members in SHGs (Rural and urban) at Chitradurga district under Stree Shakti from the year 2008-11

\begin{tabular}{|l|r|r|r|}
\hline District/Taluk & \multicolumn{3}{|c|}{ No. of self help groups (Rural) } \\
\hline & $2008-9$ & $2009-10$ & $2010-11$ \\
\hline Chitradurga & 18223 & 17114 & 16778 \\
\hline Challakere & 11432 & 11787 & 11817 \\
\hline Hiriyur & 13995 & 13750 & 13750 \\
\hline Holalkere & 12063 & 12063 & 12063 \\
\hline Hosadurga & 17657 & 17642 & 17642 \\
\hline Molakalmuru & 7315 & 7495 & 7495 \\
\hline Total & 80685 & 79851 & 79545 \\
\hline
\end{tabular}


SHG members are playing a very imperative role in the formation of SHGs. Generally SHG consists of 10-20 people. Minimum number is 10 and maximum number is 20 . It can be observed through the above table that urban SHGs numbers are gradually increased and in rural SHGs numbers have come down. Though, numbers of SHGs are less in urban, the members increased gradually, and it indicates that in urban counterpart SHGs started gaining momentum.

Number of members indicates strength of the groups and its helps in the growth of the group. If the number is more, the savings will be high. Mobilization of savings increases lending capacity. Meanwhile, it avoids taking loan from outsiders. In Chitradurga district, members in a group diminished to $1 \%$ year by year. It's not a good sign, if the members go below 10, and the group cannot be continued. Only Challakere has got positive sign in the form of growth. Holalkere has got constant members. Rest all other taluk members got minimized slightly. Consequences are worst in the case of debt. Since when debt goes as bad, it is going to become burden for the few people who remain in the group, and the internal lending is going to become tiny; repayment power comes down. To overcome this problem, government has to take necessary action by conducting promotional activities and awareness Programme of SHGs.

\section{Gradings and awards of SHGs}

Grading of SHGs is one of the important factors to evaluate performance of the SHG. Usually grading will be done based on these parameters:

I. Quantum of savings

II. Internal lending and repayment structure

III. Operations of SHGs (conducting meeting, solving problems among SHG members, planning for economic development of the group, etc.)

IV. Socio-economic development among members

V. Any socio or economic activities conducted for the sake of village

VI. External lending and repayment structure 
Better grading gives reputation and image to SHGs and gets paramount preference, while disbursing loan from banks. Taluk, district and state level Special awards are given by the government to SHGs whose performance is extremely good. One more is in the name of Smt. Yashodharamma Dasappa, to the best group for revenue division. Along with that, three awards are reserved for block level societies in each district. During 2011-12, Rs 12.10 lakh rupees are sanctioned for the same. Below table explains about grading of SHGs. " $\mathrm{A}$ " is the first rating and " $\mathrm{B}$ " is the second rating. In Chitradurga district, all SHGs have got ratings either " $A$ " or "B", but noticeable element is that $72 \%$ of the SHGs got grade $\mathrm{A}$ and $28 \%$ of SHGs got grade $\mathrm{B}$. It's a good indication since, majority of the SHGs got grade A for their performance. Grade "A" helps in many manners like getting awards, incentives, loan from financial institutions, etc.

Table 5: Talukwise grading of SHGs in Chitradurga district under Stree Shakthi from the year 2008 2011

\begin{tabular}{|l|r|r|r|r|r|r|}
\hline District /Taluk & \multicolumn{3}{|c|}{ Rural SHGs } & \multicolumn{3}{c|}{ Urban SHGs } \\
\hline & \multicolumn{1}{c|}{ A } & \multicolumn{1}{c|}{ B } & Total & A & B & Total \\
\hline Chitradurga & 730 & 370 & 1100 & 60 & 25 & 85 \\
\hline Challakere & 480 & 193 & 673 & 16 & 14 & 30 \\
\hline Hiriyur & 575 & 330 & 905 & 36 & 4 & 40 \\
\hline Holalkere & 530 & 120 & 650 & 16 & 4 & 20 \\
\hline Hosadurga & 691 & 299 & 990 & 16 & 14 & 30 \\
\hline Molakalmuru & 463 & 30 & 493 & 10 & 0 & 10 \\
\hline Total & 3469 & 1342 & 4811 & 154 & 61 & 215 \\
\hline
\end{tabular}

Source: survey data

\section{Financial benefits of the programme}

\section{Savings}

Savings is the main precept of SHG Programme. Mobilized fund as savings can be used for lending purpose. So that needy people can make use of that at a lower rate of interest. On the other hand, those who have contributed for savings can get the benefit in the form of interest. This act offers them two specific advantages- saving and interest. 
Table 6: Talukwise grading of SHGs in Chitradurga district under Stree Shakti from the year of $2008-2011$

\begin{tabular}{|l|c|c|r|}
\hline District /Taluk & A & B & Total \\
\hline Chitradurga & 790 & 395 & 1185 \\
\hline Challakere & 496 & 207 & 703 \\
\hline Hiriyur & 611 & 334 & 945 \\
\hline Holalkere & 546 & 124 & 670 \\
\hline Hosadurga & 707 & 313 & 1020 \\
\hline Molakalmuru & 473 & 30 & 503 \\
\hline Total & 3623 & 1403 & 5026 \\
\hline
\end{tabular}

Source: survey data

This evades them taking loan from outsiders. Loan amount which is taken by SHGs members can be used for productive purpose to improve their economic condition. As per the record, SHG members have saved Rs 971.84 cores since inception in Karnataka state till 2011-12.

Table 7: Talukwise Annual Savings of SHGs in Chitradurga district under Stree Shakthi from the year of 2008 - 2011. (In Lakhs)

\begin{tabular}{|l|r|r|r|r|r|r|}
\hline District / Taluk & \multicolumn{3}{|c|}{ Annual savings (Rural) } & \multicolumn{3}{c|}{ Annual savings (urban) } \\
\hline & $2008-09$ & $2009-10$ & $2010-11$ & $2008-09$ & $2009-10$ & $2010-11$ \\
\hline Chitradurga & 129.86 & 142.72 & 110.42 & 10.23 & 9.1 & 10.35 \\
\hline Challakere & 50.59 & 58.13 & 60.05 & 0.16 & 0.16 & 0.13 \\
\hline Hiriyur & 71.78 & 85.61 & 80.5 & 4.96 & 5.1 & 5.4 \\
\hline Holalkere & 80.7 & 76.7 & 76.01 & 3.73 & 3.42 & 3.41 \\
\hline Hosadurga & 99.5 & 117.69 & 102.56 & 8.4 & 8.22 & 8.32 \\
\hline Molakalmuru & 36.59 & 36.93 & 45.35 & 4.62 & 4.7 & 4.78 \\
\hline Total & 469.02 & 517.78 & 474.89 & 32.1 & 30.7 & 32.39 \\
\hline
\end{tabular}

Source: survey data

Rural SHGs savings are more than urban SHGs, since SHG numbers are more in rural counterpart. Again rural counterpart has done good savings with $10 \%$ and $1 \%$ of growth in the year of 200910 and 2011. In urban counterpart there is a decrease of $4 \%$ in the year of 2009-10, but slight growth of $1 \%$ can be seen in the year of 2010-11. 
Table 8: Talukwise Total Annual Savings of SHGs in Chitradurga district under Stree Shakthi from the year of 2008 - 2011. (In Lakhs)

\begin{tabular}{|l|r|r|r|}
\hline District /Taluk & $2008-09$ & $2009-10$ & $2010-2011$ \\
\hline & savings & savings & savings \\
\hline Chitradurga & 140.09 & 151.82 & 120.77 \\
\hline Challakere & 50.75 & 58.29 & 60.18 \\
\hline Hiriyur & 76.74 & 90.71 & 85.9 \\
\hline Holalkere & 84.43 & 80.12 & 79.42 \\
\hline Hosadurga & 107.9 & 125.91 & 110.88 \\
\hline Molakalmuru & 41.21 & 41.63 & 50.13 \\
\hline & 501.12 & 548.48 & 507.28 \\
\hline
\end{tabular}

Source: survey data

Over all savings is not up to the mark since, $10 \%$ of the growth in the year of 2009-10 and only 1\% of growth in the year of 2010-11. Main reason in the reduction of savings is decline in number of members. Except Molakalmuru and Challakere, all other taluks' SHGs savings have come down either in the year of 2009 or 2010. However, overall savings is good in the year of 2009-10.

In Chitradurga district SHGs are foremost in all years, but in 201011 it lost by $14 \%$. After Chitradurga, Hosadurga is doing better. Then, Hiriyur, Holalkere, Challakere and Molakalmuru are coming in the next sequence. Comparing to $2008-09$ savings, $10 \%$ and $1 \%$ of growth have been seen in the years of 2009-10 and 2010-11 respectively. It's a good indication but not up to the mark.

\section{Incentives for excess savings}

To encourage more and more savings and to identify extraordinary performance of the SHGs, incentive of Rs 15,000 is given to those SHGs who save more than Rs 75,000 and Rs 20,000 is given who saves more than Rs 1.00 lakh. During 2011-12, Rs 40.00 lakhs is given as incentives to 200 groups in Karnataka state.

\section{Internal lending}

Internal lending is nothing but amount which is saved by SHG members will be lent to the needy members in the group at a lower rate of interest. As a result, that interest benefit can be enjoyed by members depending upon their contribution in the savings. It is 
also helpful for the lender as well as to the borrower, because the lender gets interest and the borrower gets loan without any difficulty at lower interest rate. It is one of the main sources of fund for SHG members. Repayment of loan is one more source of fund to relend. This process is like a cycle as it goes from one hand as a loan and comes from another hand by repayment of loan. Loan repayment is monthly once, weekly once or fortnightly once depending upon the decision taken by the SHG leaders. Everything will be recorded and follow up will be done continuously. Repayment is very important otherwise more debt leads to burden for remaining members and it may cause for the closure of SHG. To run SHG, proper maintenance of accounting and follow up is very much needed and the members should be prompt enough. Then only SHG can function without any obstacles.

Table 9: Talukwise Internal Lending and Repayment of SHGs in Chitradurga District under Stree Shakthi Programme from the year of 2008 - 2011. (In Lakhs)

\begin{tabular}{|l|r|r|r|r|r|r|}
\hline District/Taluk & \multicolumn{1}{|c|}{ Lending } & Repayment & Lending & Repayment & Lending & Repayment \\
\hline & $2008-09$ & \multicolumn{1}{|c|}{$2008-09$} & $2009-10$ & $2009-10$ & $2010-11$ & \multicolumn{1}{c|}{$2010-11$} \\
\hline Chitradurga & 337.07 & 240.72 & 280.7 & 233.2 & 286.73 & 244.83 \\
\hline Challakere & 12.93 & 11.45 & 12.32 & 10.51 & 13.27 & 12.35 \\
\hline Hiriyur & 164.28 & 144.05 & 201.29 & 190 & 174.9 & 162.2 \\
\hline Holalkere & 239.85 & 278.36 & 215.89 & 216.16 & 180.79 & 197.82 \\
\hline Hosadurga & 391.55 & 342.13 & 402.18 & 350.53 & 329.48 & 307.96 \\
\hline Molakalmuru & 82 & 59.4 & 90.89 & 63.22 & 71.3 & 55.04 \\
\hline & 1227.68 & 1076.11 & 1203.27 & 1063.62 & 1056.47 & 980.2 \\
\hline
\end{tabular}

Source: survey data

Above picture talks about loan lent and repayment from 2008-2011. Though lent amount has come down $2 \%$ and $14 \%$ respectively from 2008 to 2009 and 2010 respectively. Here the repayment is notable. In 2008 and 2009 nearly $88 \%$ loan amount has been repaid and in the year of 2010, 93\% loan amount is repaid. Her, it seems very virtuous repayment comparing to the previous repayment. It seems to look at amount availed as loan is used for the productive purpose only. Otherwise repayment amount would have been less. In Holalkere taluk, remarkable repayment has taken place, that is over the loan amount repayment, has taken the place. It means 
outstanding loan amounts repayment has taken place drastically across all three years.

\section{Revolving fund}

A group which has maintained savings at least for six months is eligible to get revolving fund of Rs 5000. The members will start loan activities by using their savings amount and revolving fund initially. The supervisors and assistant child development project officer will regularly examine and get ensured that the members are repaying the loans in time and money is not misused in any manner.

Table 10: Talukwise Revolving fund availed by SHGs in Chitradurga district under Stree Shakti from the year of $2008-2011$

\begin{tabular}{|c|c|c|c|c|c|c|}
\hline \multicolumn{2}{|c|}{ District / Taluk } & \multicolumn{2}{|c|}{$\begin{array}{l}\text { Revolving fund } \\
\text { details (Rural) }\end{array}$} & \multicolumn{3}{|c|}{$\begin{array}{l}\text { Revolving fund details } \\
\text { (urban) }\end{array}$} \\
\hline & 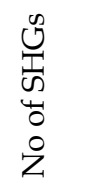 & 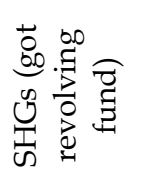 & 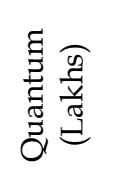 & 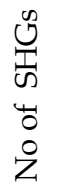 & 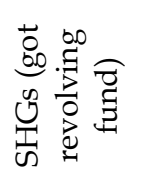 & 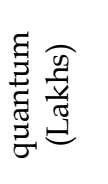 \\
\hline "Chitradurga & 1100 & 1100 & 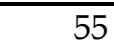 & 85 & 85 & 4.25 \\
\hline Challakere & 6880 & 680 & 34 & 30 & 30 & 1.5 \\
\hline Hiriyur & 850 & 850 & 42.5 & 40 & 40 & 2 \\
\hline Holalkere & 650 & 650 & 32.5 & 20 & 20 & 1 \\
\hline Hosadurga & 990 & 990 & 49.5 & 30 & 30 & 1.5 \\
\hline Molakalmuru & 463 & 463 & 23.15 & 10 & 10 & 0.5 \\
\hline Total & 4733 & 4733 & 236.65 & 215 & 215 & 10.75 \\
\hline
\end{tabular}

Source: survey data

The above table explains about number of SHGs, got revolving fund and quantum of the revolving fund. In Chitradurga district, all SHGs have got revolving fund. Total disbursed amount for SHGs is Rs 247.4 Lakhs. Main objective of the revolving fund is to encourage entrepreneurial activities among the SHG members. 
Table 11: Talukwise quantum of revolving fund availed by SHGs in Chitradurga district under Stree Shakti from the year of 2008 - 2011(In Lakhs)

\begin{tabular}{|l|r|r|r|}
\hline District /Taluk & \multicolumn{1}{|c|}{ Rural } & Urban & \multicolumn{1}{c|}{ Total } \\
\hline Chitradurga & 55 & 4.25 & 59.25 \\
\hline Challakere & 34 & 1.5 & 35.5 \\
\hline Hiriyur & 42.5 & 2 & 44.5 \\
\hline Holalkere & 32.5 & 1 & 33.5 \\
\hline Hosadurga & 49.5 & 1.5 & 51 \\
\hline Molakalmuru & 23.15 & 0.5 & 23.65 \\
\hline
\end{tabular}

Source: survey data

Table 12: Talukwise total quantum of revolving fund availed by SHGs in Chitradurga district under Stree Shakti from the year of 2008 - 2011 (In Lakhs)

\begin{tabular}{|l|r|}
\hline $\begin{array}{l}\text { District } \\
\text { Taluk }\end{array}$ & Amount of Revolving Fund \\
\hline Chitradurga & 59.25 \\
\hline Challakere & 35.5 \\
\hline \hline Hiriyur & 44.5 \\
\hline \hline Holalkere & 33.5 \\
\hline Hosadurga & 51 \\
\hline \hline Molakalmuru & 23.65 \\
\hline Total & 247.4 \\
\hline
\end{tabular}

Source: survey data

\section{Fair price shops}

To market products of the SHGs, local market fair price shops are provided especially in rural places, so, SHG members can market their products without intervention of the brokers. Moreover, the way it is very much helpful, because SHG members can avoid travelling to other places to sell their goods and they can save brokerage fees and other expenses. And they feel more comfortable and relaxed to sell their commodities in their own place.

\section{Linkage with banks}

Those SHGs, worked for at least six months actively can link their SHGs in to banks for banking. Even SHGs can get subsidized loan on their quantum of savings. They should have good savings and good track record of repayment to avail loan from bank 
subsequently for their economical activities. NABARD and national women cell have given prior importance and ordered all banks to sanction certain percent of loan to SHGs.

\section{External lending and repayment (Loan from banks, financial institutions and repayment)}

External loan is another main source of fund which is available from bank in which they do deposits and withdrawal through their savings account. To start income generating activities or to expand existing business, members take loan from banks. In Chitradurga district, the SHG members have started many small business such as beauty salons, provisional store, animal husbandry, preparing wire bags, preparation of roti, tailoring, fire wood depot, manufacturing of the mosquitoes net, etc. When loan is taken by the group, an entire group is responsible to repay the loan amount. As per NABARD guidelines, banks have to give specified loan to priority sector out of total lending. SHG lending is a part of priority lending. And even, it has been proved that repayment is pleasant from SHGs and less NPA (non-performing asset) comparing to other lendings.

Table 13: Talukwise external Lending and repayment of SHGs in Chitradurga district under Stree Shakti from the year of 2008 - 2011 (Rs laks).

\begin{tabular}{|c|c|c|c|c|c|c|}
\hline District /Taluk & Lending & $\begin{array}{c}\text { Re- } \\
\text { payment }\end{array}$ & Lending & $\begin{array}{c}\mathrm{Re}- \\
\text { payment }\end{array}$ & Lending & $\begin{array}{c}\text { Re- } \\
\text { payment }\end{array}$ \\
\hline & 2008-09 & 2008-09 & $2009-10$ & $2009-10$ & $2010-11$ & $2010-11$ \\
\hline Chitradurga & 145.92 & 172.42 & 179.92 & 190.4 & 193 & 225.57 \\
\hline Challakere & 7.05 & 4.96 & 5.81 & 6.24 & 3 & 6.94 \\
\hline Hiriyur & 53.15 & 67.32 & 45.8 & 113.83 & 12.35 & 63.1 \\
\hline Holalkere & 195.59 & 147.82 & 136.65 & 161.65 & 87.33 & 169.44 \\
\hline Hosadurga & 186.29 & 124.16 & 234.79 & 132.37 & 177.59 & 329.75 \\
\hline Molakalmuru & 37.07 & 18.78 & 17 & 16.1 & 12.6 & 17.21 \\
\hline Total & 625.07 & 535.46 & 619.97 & 620.59 & 485.87 & 812.01 \\
\hline
\end{tabular}

Source: survey data

SHGs borrowings came down year by year with the percentage of 83 and 69 between 2008 and 2011. It clinches that SHGs started to borrow more from internal source than external source and dependency level has come down on banks. Looking into 
repayment, drastic repayment has taken place. In the year 2008-09, $85 \%$ of the loan amount has been repaid, $2009-10,100.10 \%$ of the loan amount, and lastly $167 \%$ of the loan amount has been repaid. In 2009-11 repayment includes previous year's loan amount also.

\section{Coordination of different service}

Depending upon the successful functioning of the self-help groups, opportunity will be given to the members to make use of the development services available in various departments and information will be given regarding these departments. Financing institutions will be introduced and action will be taken to get loans. Literacy Programme for uneducated women members of self-help groups will be made available through adult education department. Opportunity for higher education will be provided through IGNOU. In order to involve rural women in financial activities, attempts will made to coordinate their activities with the government's self-employment scheme/ swarnajayanthi swayam Udyoga Yojana. The activities that are helpful for women in the developmental departments such as agriculture, horticulture, industry, rural development will be available. Importance will be given to health and education to improve health and nutrition aspects of women.

\section{Taluk marketing complex}

To market the products which are prepared by SHGs, special marketing complexes are provided in each taluk by the government; therefore, SHGs can take up income generating activities and sell it off within their locality without any geographical trouble.

\section{Skill development programme}

During 2010-11, Rs 300.00 lakhs is sanctioned for the construction of Two Divisional Level Training Centres and Marketing Complexes at Bangalore \& Gulbarga to enable training of the Stree Shakti Groups \& marketing of the products prepared by them. Many development trainings are conducted by Government of Karnataka to strengthen SHG groups to involve themselves in economical based activities. An amount of Rs 25.00 lakhs has been released for 83 block societies up to January 2010. 
Table 14: Talukwise Trained SHG members in Chitradurga district under Stree Shakti from the year of 2008 - 2011.training of SHG members

\begin{tabular}{|l|r|l|l|r|}
\hline & $\begin{array}{l}\text { Total } \\
\text { number of } \\
\text { members } \\
\text { (Rural) }\end{array}$ & $\begin{array}{l}\text { trained } \\
\text { members } \\
\text { (Urban) }\end{array}$ & $\begin{array}{l}\text { Total number } \\
\text { of members } \\
\text { (Rural) }\end{array}$ & $\begin{array}{l}\text { trained } \\
\text { members } \\
\text { (Urban) }\end{array}$ \\
\hline Chitradurga & 15272 & 2200 & 1506 & 85 \\
\hline Challakere & 11284 & 1360 & 533 & 30 \\
\hline Hiriyur & 12860 & 1700 & 890 & 40 \\
\hline Holalkere & 11700 & 1300 & 363 & 20 \\
\hline Hosadurga & 17102 & 1980 & 540 & 30 \\
\hline Molakalmuru & 7320 & 926 & 175 & 10 \\
\hline Total & 75538 & 9466 & 4007 & 215 \\
\hline
\end{tabular}

Source: survey data

Training is needed to improve socio and economic skills of SHG members. It helps in upgrading themselves. So many training and development activities are conducted by concerned authorities. So far $13 \%$ of the rural SHGs and 5\% of urban SHGs have got training. The number of trained members is less when compared to total number of members, since it is difficult to give to all SHGs due to many constraints. Whoever gets training, the trained educates the rest of the members, so that collectively all members can get the benefit of that training programme. In rural SHGs, 2 members each and 1 member each from urban SHGs have taken the training.

\section{Strengthening of cluster/taluk level societies}

During 2011-12, Rs 31.50 lakh is released to conduct training programme for 226 batches. During 2010-11, training was conducted with the co-ordination of NABARD and MYRADA and $t$ 1,750 main members got trained for 5 days in 58 batches from 175 taluks.

\section{Taluk/block level societies}

Under Karnataka Society's Registration Act, 1960, taluk level societies have been registered in 175 taluks and provided Rs 30,000 financial assistance for each society to strengthen SHGs financially. Up to end of August 2011, Rs 52.50 lakhs is sanctioned. 


\section{Income generating activities}

Main intent of the Programme is to take up some economical activities either by group or individual member of SHG. Incentive of Rs 5000 is given to those SHGs who come forward to take up income generating activities. Rs 17.90 lakhs is released to 358 groups up to the end of August-2011.

\section{Exhibition and marketing melas}

District level exhibition and marketing melas will be conducted to promote products of SHGs. To organize this Rs 75,000 is released for each district. During 2011-12, 30 districts are given Rs 22.50 lakhs.

\section{Subsidy}

Groups formed by the Department of Social Welfare Co-operation and Rural Development Department of Women and Child Development are eligible to get subsidy of $6 \%$ for the loan availed by the bank loans up to Rs 1.00 lakh. During 2011, Rs 95.46 lakhs got released to 4,370 groups as subsidy.

\section{SHG members talk about the programme}

Respondent one (from Chitradurga)- One of the widow SHG members said, "when I wanted to borrow money from outsiders, they use to ask many questions and they were rejecting to lend, and they were asking how can you pay? But now I don't have such problems; we can discuss in the meeting and decide to take loan. And now I started my own business of tea shop. It is running well and almost $90 \%$ of the loan I have repaid so far. After completion of this I am taking some more loans to extend my business".

Respondent Two (from Challakere) "Now we are not depending upon money lenders. Earlier I have taken at the rate of $7 \%$, and before lending they made me to walk many times from my house to the lender's house. Rate of interest is too high and in the case of default he usees to rebuke very badly. But after joining SHG I was able to get loan at just for $2 \%$. So it is very cheap and it can be returned in monthly instalment; if not after that month at a time we can repay. This kind of adjustments was not there with outsiders". 
Respondent Three (from Hiriyur) "Earlier getting loan from bank was so difficult and we use to take middleman's help to avail loan. And we were giving minimum of $10 \%$ of the loan amount as his commission, but now we don't have such problems. Whenever we go to bank for asking for loan, they respect us and easily they provide loan without any interruption".

Respondent Four (from Molkalmuru) "We work from home, and we meet whenever we are free to discuss the status of SHG and plan for the future. We are able to manage both and we feel like now we are something instead of nothing. And also we will get to know each other and we spend part of the time in productive work".

Respondent Five (from Holalkere): "Before joining SHG, I was very much neglected by my son and daughter in-law but now I have joined the SHG and started to do some savings. I can look after my own expenses without asking money from my son. Now they started to give respect, and sometimes they only take money from me. I am of proud myself since I help them at this age also.

Respondent Six (from Hosadurga)- "Earlier I was tortured by all my family members. My in-laws were always threatening me to get dowry. I did not know about laws which can protect women regarding this. After joining SHG, I came to know about all these. Once I told to my in-laws that I would go legally, if the same thing continued. I got courage after joining SHG. Now I can speak in front of my husband and in-laws without fear, since I don't feel alone because all the time the other members of SHG support me.

\section{Conclusion}

Some of the important things can be noticed about the SHGs in Chitradurga distirct:

1. The number of Members has come down slightly; it is not good indication, because savings has come down drastically.

2. Regarding internal loan and external loan both slightly decreased, but repayment is indeed noticeable. 
3. Majority of the SHGs have got grade " $A$ ". It is a good sign that makes SHGs to get revolving fund and incentives.

4. Overall performance is satisfactory.

From the above study the researcher has found many important factors relating to Stree Shakti Programme and SHG model. SHG model turned into the sturdiest model to improve socio-economic status of poor women in rural and urban areas. Though this Programme started in the year of 2000, remarkable improvement has taken place over a period of 11 years. Now SHG members are quite confident, independent and free to take necessary decision without depending on anybody. It has been revealed through interaction with SHG members, but still awareness is very less. Many women don't know about this programme. Here, the government has to take necessary action to create awareness among rural people. And this kind of programmes should come more and more, so that poverty can be eliminated completely in Karnataka.

\section{References}

Records of Women and child development office of Chitradurga district

Records of women and Child development office of Chalkere, Hiryur, Molkalmuru, Holalkere and Hosadurga taluks

Stree Shakti Programme Brochure

http:/ /dwcdkar.gov.in/index.php?option=com_content\&view=article\&id $=260 \% 3$ Astree\&catid $=224 \% 3$ Aflash\&lang=en 